\title{
Factors Influencing Particulate Emissions during Iron Ore Sintering
}

\author{
David DEBRINCAT and Chin Eng LOO \\ BHP Billiton - Newcastle Technology Centre (NTC), PO Box 188, Wallsend 2287, Australia. \\ E-mail: David.debrincat@bhpbilliton.com, bob.ce.loo@bhpbilliton.com
}

(Received on January 19, 2006; accepted on February 26, 2007)

\begin{abstract}
Controlling particulate emission from a sinter strand is important to minimizing its impact on the environment. Several factors influencing particulate emission from an iron ore sinter strand were investigated in the current work using a laboratory scale sinter pot. A blend fairly typical of that currently used in the Asia Pacific region, as well as another containing 30 mass\% Marra Mamba ore that could represent a future ore blend were used. It was established that most of the particulates emitted were less than $1.18 \mathrm{~mm}$ and were mostly from the calcination and dried zones of the bed. In addition, most particulates were released from the bed after the wet zone in the bed had ceased to exist. This work suggests mix moisture and coke rate had a significant impact on particulate emissions. Increasing moisture from 5.5 to 9.0 mass \% decreased particulate emission while increasing coke content from 5.5 to 7.5 mass \% increased particulate emission. Therefore when altering the ore blend changes in mix moisture and coke rate may also need to be accounted for when evaluating the impact on particulate emission. It was also found that particulate emission could be decreased by decreasing sintering suction just before burn-through.
\end{abstract}

KEY WORDS: iron ore sintering; particulate emission; coke rate; moisture; Marra Mamba ore.

\section{Introduction}

The sinter strand is a major contributor to the particulate emission from an integrated iron and steel works. ${ }^{1)}$ Over the years, major effort has been invested in cleaning the off-gas from a sinter strand and a number of different technologies are available. Plants will be placed under increasing pressure to further decrease emissions as legislated limits become more and more stringent. Dust from the strand and room de-dusting are two major sources of emissions from a sinter plant. Particulate emission through the wind-boxes represents about $60 \%$ of the total particulate emission from the strand ${ }^{2)}$ and is considered in the current work. The ability to reduce emission from the strand will reduce the work load of gas cleaning facilities and also assist plants to achieve their emission targets.

Plant research ${ }^{2)}$ has indicated that the properties and amount of emitted dust was dependent on:

- raw material properties - the amount of fine material in the raw mix and micro-pellet strength,

- plant variables - mix moisture, granulation time, use of hearth layer, maintenance of grate bars, strand speed and off-gas flow rate.

The concentration of dust in the off-gas was found to be highest in the early stages of sintering, which decreases to very low values along the middle of the strand that increases towards the end of the strand. The chemical composition of the dust varied from plant to plant, and was dependent on the blend components. Studies carried out using a laboratory scale unit concluded that dust was emitted after the drying zone has reached the bottom of the bed. ${ }^{3)}$ In addition, only $20 \%$ of the collected dust was below $300 \mu \mathrm{m},{ }^{3)}$ suggesting that most of it would drop out of the gas stream and not be carried out through the sinter stack.

This study was carried out to further understand the factors that influence particulate emission. Variables considered were: air flow, coke rate, moisture level, and ore type.

\section{Release of Particulates during Sintering}

Figure 1 shows that during sintering, the green bed is transformed into several zones - the sintered bed, the flame-front, the calcined bed, the dried bed, and the humidified bed. It is unlikely there will be many free particles in the sintered bed. In the humidified bed strong capillary forces should be able to restrain particles from being entrained into the gas stream. However, the release of particles from other regions of the bed is possible for the following reasons:

Dried bed: the strong capillary forces holding granules together are no longer there,

Calcination bed: calcination can result in the decrepitation of particles and the formation of fines, and

Flame-front zone: high temperatures can cause the formation of substances such as $\mathrm{KCl}$ fume.

These three zones are sandwiched between the sintered and wet zones. During sintering the wet zone should act like a wet scrubber for the flowing gases, and so an accumulation of captured particles just after the dried zone is expected and there is evidence that this is the case. ${ }^{4)}$ 


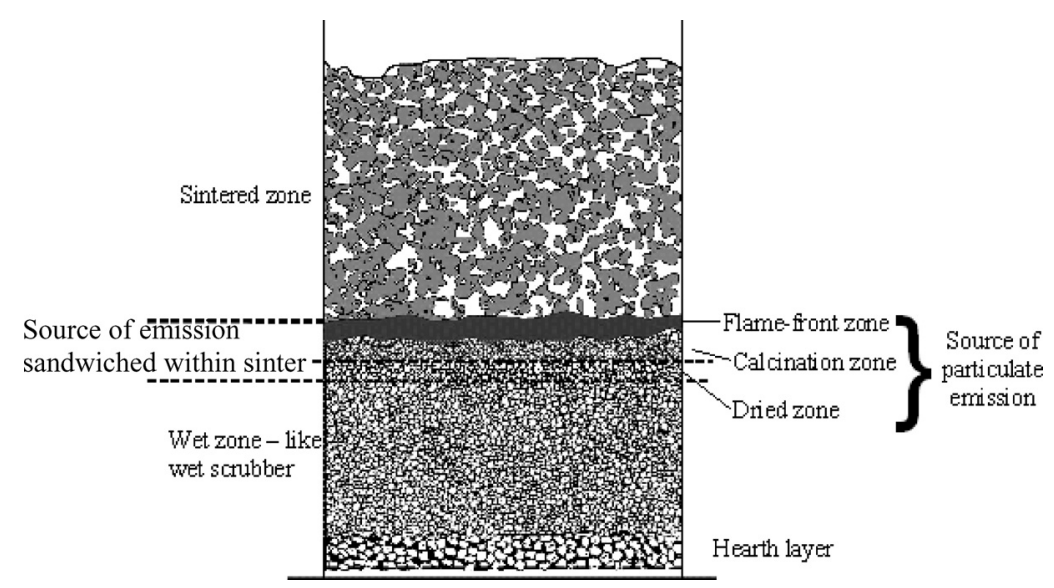

Fig. 1. Schematic diagram showing different zones present in a sinter bed and where the source of emission is located.

Table 1. Components used in Base blend and Blend 1.

\begin{tabular}{|l|c|c|}
\hline $\begin{array}{c}\text { Component } \\
\text { (mass \% dry } \\
\text { ore basis) }\end{array}$ & Base blend & Blend 1 \\
\hline ORES & & \\
\hline Ore N & 15 & 6 \\
\hline Ore C & 30 & 12 \\
\hline Ore Y & 50 & 50 \\
\hline Ore B & 5 & 2 \\
\hline Ore M & 0 & 30 \\
\hline FLUXES & & 15.4 \\
\hline Limestone & 16.8 & 2.4 \\
\hline Serpentine & 3.8 & 2.7 \\
\hline Dolomite & 0.4 & \\
\hline
\end{tabular}

For particle release the detachment force needs to exceed the adhesion force. Adhesion forces, excluding the wet zone, include:

- solid bridges, formed as moisture is dried from the granules e.g., clays present,

- frictional forces, which are dependent on the number of inter-particle contact points, and

- short range forces, such as van der Waals.

The drag imparted by the flowing gas would be the main cause of detachment. The break-down of particles because of thermal shock or calcination is likely to weaken interparticle adhesion and lead to their entrainment in the gas stream.

An entrained particle can either deposit further down in the wet zone of the bed or leave the bed with the gas stream, which depends on the particle inertia and drag force.

\section{Experimental Details}

\subsection{Raw Material Preparation and Characterisation}

Table 1 shows the two ore blends studied. The composition of the base blend is similar to blends used in the Asia Pacific region. For Blend 1, Ore Y was kept at 50 mass\%, dry ore basis while all other ores were reduced proportionally to allow for the introduction of Ore M. The addition of fluxes had to be varied slightly to maintain a target sinter $\mathrm{SiO}_{2} \%$ of $4.9 \%$, basicity $\left(\mathrm{CaO} / \mathrm{SiO}_{2}\right)$ of 1.8 , and $\mathrm{MgO} \%$ of $1.5 \%$.

The size distributions of iron ores, fluxes and coke are shown in Fig. 2. The coke breeze and limestone are rela-

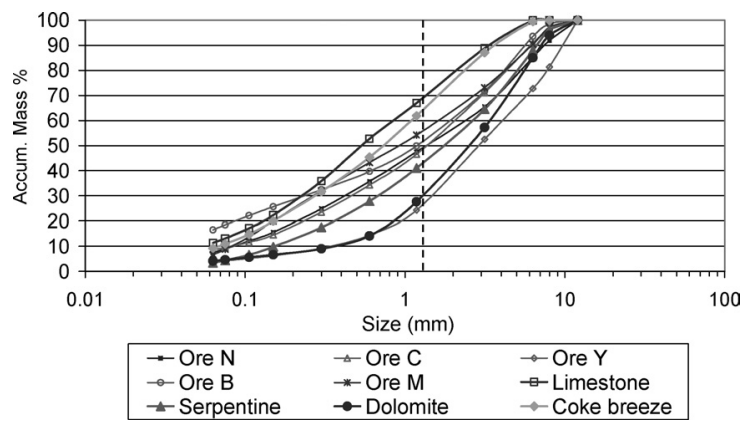

Fig. 2. Size distribution of iron ores, fluxes and coke in blend.

Table 2. Chemical composition of iron ores.

\begin{tabular}{|l|c|c|c|c|c|}
\hline $\begin{array}{l}\text { Component } \\
\text { (mass\%) }\end{array}$ & Ore N & Ore C & Ore Y & Ore B & Ore M \\
\hline $\mathrm{Fe}(\mathrm{Total})$ & 64.2 & 67.3 & 58.3 & 67.2 & 62.2 \\
\hline $\mathrm{SiO}_{2}$ & 3.3 & 0.9 & 5.1 & 1.4 & 3.0 \\
\hline $\mathrm{Al}_{2} \mathrm{O}_{3}$ & 2.0 & 0.9 & 1.3 & 1.0 & 1.7 \\
\hline $\mathrm{MgO}$ & 0.10 & 0.09 & 0.06 & 0.05 & 0.12 \\
\hline $\mathrm{CaO}$ & 0.03 & 0.06 & 0.11 & 0.06 & 0.07 \\
\hline $\mathrm{K}_{2} \mathrm{O}$ & 0.009 & 0.014 & 0.006 & 0.009 & 0.028 \\
\hline $\mathrm{S}$ & 0.010 & 0.007 & 0.011 & 0.005 & 0.041 \\
\hline $\mathrm{P}$ & 0.064 & 0.029 & 0.039 & 0.040 & 0.057 \\
\hline Ign. Loss & 2.3 & 1.0 & 9.7 & 0.8 & 5.1 \\
\hline
\end{tabular}

Table 3. Chemical composition of fluxes and coke breeze.

\begin{tabular}{|l|c|c|c|c|}
\hline $\begin{array}{l}\text { Component } \\
\text { (mass\%) }\end{array}$ & Limestone & Serpentine & Dolomite & Coke breeze \\
\hline $\mathrm{Fe}($ Total) & 0.2 & 5.9 & 0.9 & 0.7 \\
\hline $\mathrm{SiO}_{2}$ & 0.4 & 40.1 & 1.1 & 6.6 \\
\hline $\mathrm{Al}_{2} \mathrm{O}_{3}$ & 0.1 & 1.9 & 0.3 & 3.8 \\
\hline $\mathrm{MgO}$ & 0.6 & 36.1 & 20.5 & 0.1 \\
\hline $\mathrm{CaO}$ & 54.6 & 2.0 & 29.9 & 0.4 \\
\hline $\mathrm{K}_{2} \mathrm{O}$ & 0.030 & 0.015 & 0.040 & 0.088 \\
\hline $\mathrm{S}$ & $<0.005$ & 0.032 & $\begin{array}{c}\text { Not } \\
\text { reported }\end{array}$ & 0.041 \\
\hline $\mathrm{P}$ & 0.008 & $\begin{array}{c}\text { Not } \\
\text { detected }\end{array}$ & $\begin{array}{c}\text { Not } \\
\text { detected }\end{array}$ & 0.060 \\
\hline Ign. Loss & 43.7 & 11.1 & $\begin{array}{c}46.2 \\
87.4\end{array}$ \\
\hline
\end{tabular}

tively fine while the dolomite is relatively coarse. Ore $\mathrm{Y}$ is much coarser than the other iron ores in the blend. The chemical composition of iron ores, fluxes and coke are given in Tables $\mathbf{2}$ and 3. The experimental conditions used in the runs conducted are summarized in Table 4.

\subsection{Emission Collection Method}

The Newcastle Technology Centre laboratory sinter pot described elsewhere ${ }^{5)}$ was modified to include an emission 
Table 4. Summary of conditions used in experiments.

\begin{tabular}{|l|c|c|c|c|c|c|c|c|c|c|c|}
\hline Run & A & B & C & D & E & F & G & H & I & J & K \\
\hline Blend & base & 1 & base & base & base & 1 & 1 & base & base & 1 & base \\
\hline $\begin{array}{l}\text { Suction } \\
\text { Pressure (kPa) }\end{array}$ & 16 & 16 & 16 & 16 & $\begin{array}{c}16 \\
(6 \text { at } \\
\text { end) }\end{array}$ & 16 & 16 & 16 & 16 & 16 & 16 \\
\hline Moisture (\%) & 7.50 & 6.83 & 6.93 & 6.73 & 6.82 & 6.94 & 6.88 & 6.10 & 8.00 & 7.20 & 6.88 \\
\hline $\begin{array}{l}\text { Coke rate } \\
\text { (mass \% dry } \\
\text { ore basis) }\end{array}$ & 6.5 & 6.5 & 6.5 & 6.5 & 6.5 & 6.5 & 6.5 & 6.5 & 6.5 & 6.5 & 6.5 \\
\hline Stopped run & No & No & No & No & No & No & No & No & No & No & Yes \\
\hline
\end{tabular}

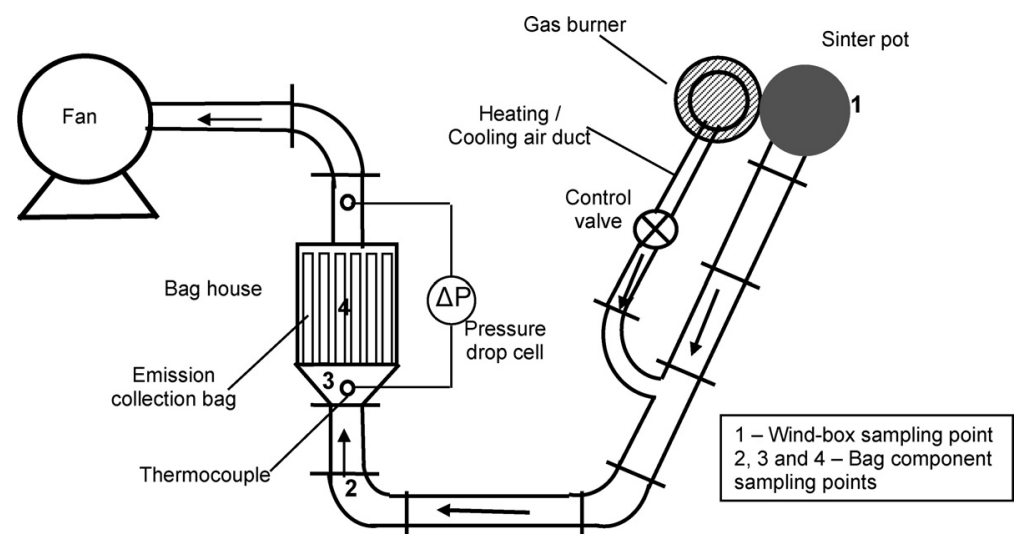

Fig. 3. Schematic diagram of laboratory sinter pot with emission collection rig.

collection rig in the off-gas pipe. The rig is shown schematically in Fig. 3. The major components for emission collection are a heating-cooling duct and a bag-house.

Bag filters were used to collect the emitted particulates. The bags were made of a fibrous Teflon that was coated with a thin membrane, also Teflon, to allow the particulates to be removed easily. These filter bags can collect particles down to $0.1 \mu \mathrm{m}$, which meant that alkali chloride fume could also be collected.

As indicated, the air duct was used to carry cold or hot air depending on the time during the sintering run. During sintering the off-gas temperature was raised from approximately $60^{\circ} \mathrm{C}$ to between $100-200^{\circ} \mathrm{C}$ by mixing it with hot air and burner off-gas to prevent moisture condensation on the filter bags. The additional heat was provided by the burner used to ignite the sinter bed, though used at a lower flame intensity. When burn-through started the burner was turned off and the duct was used for cooling. Ambient air was mixed into the off-gas stream so that its temperature was reduced to less than $250^{\circ} \mathrm{C}$.

Emission was collected from several places in the rig as shown in Fig. 3, which included:

1. Wind-box,

2. Elbow before bag-house,

3. Expanding section at entry of bag-house,

4. Collection bags.

Emission collected in the bag-house combined the material from the bags (4 in Fig. 3), the elbow immediately before the bag-house ( 2 in Fig. 3 ) and the entry of the baghouse ( 3 in Fig. 3), while the windbox emission was only from 1 in Fig. 3.

\subsection{Operation of Sinter Pot Rig}

The sinter pot had diameter $330 \mathrm{~mm}$ and height of $550 \mathrm{~mm}$ and used a $5 \mathrm{~kg}$ hearth layer of sinter in the size

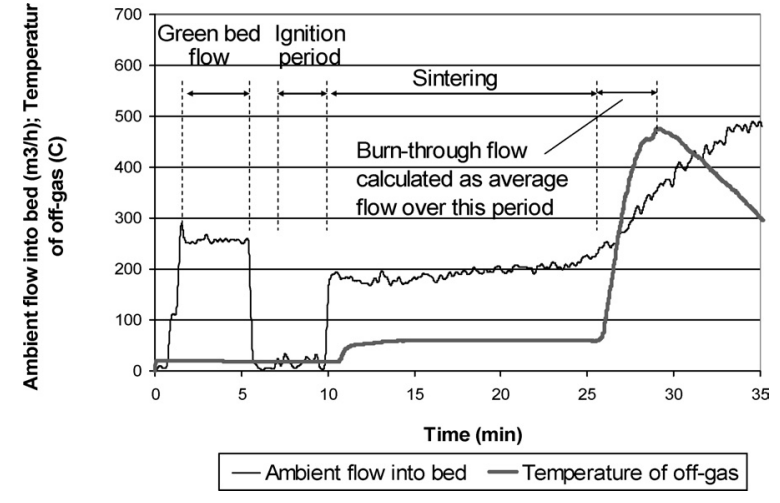

Fig. 4. Temperature and flow profile during a test showing the periods that were used to calculate the green bed flow, sintering flow and burn-through flow.

range $-8+6.3 \mathrm{~mm}$. Since the purpose of the current work was to establish relationships between particulate emission and process parameters, studying trends was a major focus and many tests conducted were not return fine balanced. A typical temperature and flow profile during a test is shown in Fig. 4.

The average flow over different times was calculated as follows:

- Green bed flow - the average flow through the green bed at a pressure drop of $6 \mathrm{kPa}$ measured for approximately 3 min before ignition.

- Sintering flow - the average flow during sintering calculated from after ignition until off-gas temperature begins to rapidly increase at end.

- Burn-through flow-the average flow calculated over the period when the off-gas temperature begins to increase at burn-through to the maximum off-gas temperature during burn-through. 


\section{Results and Discussion}

\subsection{Characteristics of Emissions}

The size distributions of particulates emitted from return fine balanced tests (Fig. 5) show they were similar, irrespective of the blend. For both blends, most particulate emission was generally $-1.18 \mathrm{~mm}$ indicating that the particulates come mostly from the adhering fines layer of granules. It was shown earlier (Fig. 2) that the $-1.18 \mathrm{~mm}$ size fraction of the blend contained more limestone and coke than the $+1.18 \mathrm{~mm}$ fraction because of their finer sizes compared to the other components of the blend. The emission from Test $\mathrm{K}$ which had been stopped just before burnthrough had finer sizes, suggesting the particulate emission from the bed becomes coarser as the flame front moves further down and the thickness of the wet zone diminishes. Although there was some variation in the emission size distri-

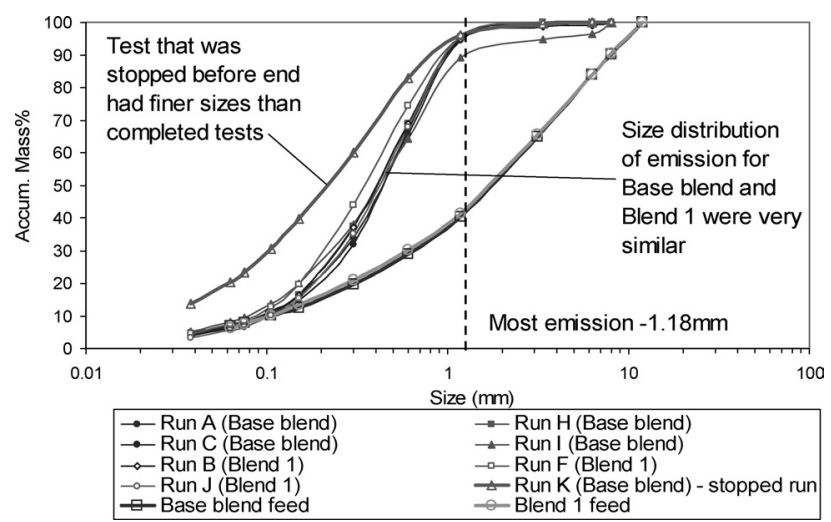

Fig. 5. Size distribution of emission from return fine balanced tests and a test stopped just before burn-through (Test K), as well as size distribution of raw mix blends (excluding $\mathrm{RF})$. bution as variables were changed in the current work, no striking effect on emission size was apparent.

Analyses of the total emission collected from tests using the Base blend and Blend 1 are compared to the starting blend compositions, as shown in Table 5. The emission had lower $\mathrm{Fe}$ and $\mathrm{LOI}$, but a higher $\mathrm{CaO}$ than the starting blend. The similar $\% \mathrm{MgO}$ and $\% \mathrm{SiO}_{2}$ suggests that mostly limestone is responsible for the increased $\mathrm{CaO}$.

On the plant the relatively larger particles will settle readily from the gas stream, but the finer particles will be more difficult to separate. Plant observations indicate the particle sizes $-0.3 \mathrm{~mm}$ are mostly collected in the electrostatic precipitator. Therefore, the emission collected in the wind-box and bag-house were screened into fractions $+0.3 \mathrm{~mm}$ and $-0.3 \mathrm{~mm}$. Analyses of the emission in these size fractions are shown in Table 6. The $\mathrm{CO}_{2}$ and total carbon contents were used to estimate the amount of carbonate and coke present in the emission respectively, summarized in Table 7. From the total amount of $\mathrm{CaO}$ and $\mathrm{CO}_{2}$ a mass balance indicated that some of the $\mathrm{CaO}$ detected was not in $\mathrm{CaCO}_{3}$. Since $\mathrm{Ca}$ is present in the ore in only very minor amounts, most of the remaining $\mathrm{Ca}$ comes from calcined

Table 5. Chemical composition of starting blend and particulate emission for Base blend and Blend 1 .

\begin{tabular}{|l|c|c|c|c|}
\hline & \multicolumn{2}{|c|}{ Base blend (Test A) } & \multicolumn{2}{c|}{ Blend 1 (Test B) } \\
\hline Mass\% & $\begin{array}{c}\text { Blend } \\
\text { composition }\end{array}$ & $\begin{array}{c}\text { Overall } \\
\text { particulate } \\
\text { emission } \\
\text { composition }\end{array}$ & $\begin{array}{c}\text { Blend } \\
\text { composition }\end{array}$ & $\begin{array}{c}\text { Overall } \\
\text { particulate } \\
\text { emission } \\
\text { composition }\end{array}$ \\
\hline $\mathrm{Fe}$ & 51.0 & 48.6 & 50.3 & 48.1 \\
\hline $\mathrm{SiO}_{2}$ & 4.4 & 4.4 & 4.3 & 4.2 \\
\hline $\mathrm{Al}_{2} \mathrm{O}_{3}$ & 1.3 & 1.4 & 1.4 & 1.5 \\
\hline $\mathrm{CaO}$ & 7.7 & 10.7 & 7.7 & 11.7 \\
\hline $\mathrm{MgO}$ & 1.3 & 1.2 & 1.3 & 1.0 \\
\hline $\mathrm{LOI}$ & 11.8 & 11.1 & 12.7 & 11.2 \\
\hline
\end{tabular}

(Note: The chemical composition of return fines was calculated assuming a weighted average of fully calcined ores and fluxes and fully combusted coke in each blend.)

Table 6. Chemical analyses of selected emission samples (Note: $\mathrm{LOI}=$ loss on ignition at $1000^{\circ} \mathrm{C}$ ).

\begin{tabular}{|c|c|c|c|c|c|c|c|c|}
\hline & \multicolumn{4}{|c|}{ Base blend } & \multicolumn{4}{|c|}{ Blend 1} \\
\hline Test & & & & & & & & \\
\hline $\begin{array}{l}\text { Sample } \\
\text { description } \\
\text { (mass\%) }\end{array}$ & $\begin{array}{l}\text { Windbox } \\
+0.3 \mathrm{~mm}\end{array}$ & $\begin{array}{l}\text { Windbox } \\
-0.3 \mathrm{~mm}\end{array}$ & $\begin{array}{c}\text { Bags } \\
+0.3 \mathrm{~mm}\end{array}$ & $\begin{array}{l}\text { Bags } \\
-0.3 \mathrm{~mm}\end{array}$ & $\begin{array}{l}\text { Windbox } \\
+0.3 \mathrm{~mm}\end{array}$ & $\begin{array}{l}\text { Windbox } \\
-0.3 \mathrm{~mm}\end{array}$ & $\begin{array}{c}\text { Bags } \\
+0.3 \mathrm{~mm}\end{array}$ & $\begin{array}{c}\text { Bags } \\
-0.3 \mathrm{~mm}\end{array}$ \\
\hline $\mathrm{Fe}$ & 51.8 & 45.4 & 45.1 & 44.3 & 51.5 & 45.3 & 43.2 & 43.4 \\
\hline $\mathrm{SiO}_{2}$ & 4.4 & 4.0 & 4.7 & 4.3 & 4.2 & 3.9 & 4.7 & 4.2 \\
\hline $\mathrm{Al}_{2} \mathrm{O}_{3}$ & 1.2 & 1.5 & 1.5 & 1.7 & 1.4 & 1.6 & 1.7 & 1.7 \\
\hline $\mathrm{CaO}$ & 8.4 & 14.2 & 10.8 & 14.5 & 9.0 & 15.0 & 12.1 & 16.1 \\
\hline $\mathrm{MgO}$ & 1.3 & 0.91 & 1.4 & 1.1 & 1.1 & 0.91 & 1.2 & 0.99 \\
\hline $\mathrm{K}_{2} \mathrm{O}$ & 0.03 & 0.12 & 0.07 & 0.11 & 0.04 & 0.099 & 0.082 & 0.11 \\
\hline $\mathrm{SO}_{3}$ & 0.35 & 2.5 & 0.76 & 1.6 & 0.44 & 2.1 & 0.83 & 1.6 \\
\hline $\mathrm{Cl}$ & 0.044 & 0.22 & 0.099 & 0.18 & 0.036 & 0.22 & 0.11 & 0.26 \\
\hline $\mathrm{CO}_{2}$ & 4.9 & 6.3 & 5.9 & 6.2 & 5.1 & 6.1 & 4.6 & 5.0 \\
\hline LOI & 9.6 & 10.9 & 15.8 & 12.5 & 9.9 & 11.0 & 17.2 & 12.6 \\
\hline Total Carbon & 5.7 & 4.8 & 10.7 & 6.5 & 6.2 & 5.3 & 13.3 & 6.9 \\
\hline
\end{tabular}

Table 7. Chemical analyses of selected emission samples.

\begin{tabular}{|l|c|c|c|c|c|c|c|c|}
\hline & \multicolumn{5}{|c|}{ Base blend } & \multicolumn{5}{c|}{ Blend 1 } \\
\hline Test & \multicolumn{3}{|c|}{ A } & \multicolumn{4}{c|}{ B } \\
\hline $\begin{array}{l}\text { Sample } \\
\text { description } \\
(\text { mass\%) }\end{array}$ & $\begin{array}{c}\text { Windbox } \\
+0.3 m m\end{array}$ & $\begin{array}{c}\text { Windbox } \\
-0.3 m m\end{array}$ & $\begin{array}{c}\text { Bags } \\
+0.3 \mathrm{~mm}\end{array}$ & $\begin{array}{c}\text { Bags } \\
-0.3 \mathrm{~mm}\end{array}$ & $\begin{array}{c}\text { Windbox } \\
+0.3 \mathrm{~mm}\end{array}$ & $\begin{array}{c}\text { Windbox } \\
-0.3 \mathrm{~mm}\end{array}$ & $\begin{array}{c}\text { Bags } \\
+0.3 \mathrm{~mm}\end{array}$ & $\begin{array}{c}\text { Bags } \\
-0.3 \mathrm{~mm}\end{array}$ \\
\hline $\mathrm{CaCO}_{3}$ & 11.1 & 14.3 & 13.4 & 14.1 & 11.6 & 13.9 & 10.5 & 11.4 \\
\hline $\mathrm{CaO}$ in $\mathrm{CaCO}_{3}$ & 6.2 & 8.0 & 7.5 & 7.9 & 6.5 & 7.8 & 5.9 & 6.4 \\
\hline $\begin{array}{l}\mathrm{CaO} \\
\text { excluding } \\
\mathrm{CaO} \text { in } \mathrm{CaCO}_{3}\end{array}$ & 2.2 & 6.2 & 3.3 & 6.6 & 2.5 & 7.2 & 6.2 & 9.7 \\
\hline $\begin{array}{l}\mathrm{C} \text { associated } \\
\text { with } \mathrm{CO}_{2}\end{array}$ & 1.3 & 1.7 & 1.6 & 1.7 & 1.4 & 1.7 & 1.3 & 1.4 \\
\hline $\mathrm{C}$ from coke & 4.4 & 3.1 & 9.1 & 4.8 & 4.8 & 3.6 & 12.0 & 5.5 \\
\hline
\end{tabular}


Table 8. Comparison of tests with $16 \mathrm{kPa}$ through entire run with tests that decreased the pressure drop to $6 \mathrm{kPa}$ at the end of sintering.

\begin{tabular}{|c|c|c|c|c|c|c|}
\hline & \multicolumn{3}{|c|}{ Base blend } & \multicolumn{3}{c|}{ Blend 1 } \\
\hline Test & $\begin{array}{c}\mathrm{C} \\
(\text { Normal) }\end{array}$ & $\begin{array}{c}\mathrm{D} \\
(\text { Normal })\end{array}$ & $\begin{array}{c}\mathrm{E} \\
(6 \mathrm{kPa} \\
\text { at end })\end{array}$ & $\begin{array}{c}\mathrm{F} \\
(\text { Normal })\end{array}$ & $\begin{array}{c}\mathrm{B} \\
(\text { Normal })\end{array}$ & $\begin{array}{c}\mathrm{G} \\
(6 \mathrm{kPa} \\
\text { at end })\end{array}$ \\
\hline $\begin{array}{c}\text { Total emission/ total } \\
\text { dry charge (g/kg) }\end{array}$ & 1.72 & 1.98 & 1.39 & 2.64 & 2.3 & 1.24 \\
\hline Moisture (mass\%) & 6.93 & 6.73 & 6.82 & 6.94 & 6.83 & 6.88 \\
\hline $\begin{array}{c}\text { Coke rate (mass\% dry } \\
\text { ore basis) }\end{array}$ & 6.5 & 6.5 & 6.5 & 6.5 & 6.5 & 6.5 \\
\hline
\end{tabular}

fluxes (mostly limestone). This indicates that some of the particulates emitted would be from the calcination zone in the sinter bed. Also a significant amount of $\mathrm{CaCO}_{3}$ was present in the emission (Table 7) present in material from the dried zone. The $\mathrm{CaCO}_{3}$ content of $-0.3 \mathrm{~mm}$ material tended to be higher than $+0.3 \mathrm{~mm}$ material which could be because of the relatively finer size of limestone (Fig. 2).

The LOI (at $1000^{\circ} \mathrm{C}$ ) of material collected in the bags was higher than for the material collected in the wind-box (Table 6). The LOI determined included the carbon content from coke, chemically bound water from goethite and carbon dioxide from fluxes in the particulate emission. In the wind-box temperatures reached $400-600^{\circ} \mathrm{C}$ while bag temperatures went to $250^{\circ} \mathrm{C}$. Goethite dehydration occurs mostly between $300-500^{\circ} \mathrm{C}^{6}$ ) and also depends on heating rate, and limestone calcination occurs at above $1250 \mathrm{~K}$. ${ }^{7}$ Therefore, from these temperatures goethite dehydration could occur in the wind-box, which would explain the lower LOI of the material collected there. However, limestone calcination was unlikely to occur at either collection point.

An estimate of carbon from coke was made using the content of $\mathrm{CO}_{2}$ and total carbon in the emission (Table 7). The base blend and blend 1 (Table 1) had 4 mass $\%$ coke and the emission from these had coke levels estimated to be 5.5 mass $\%$ and 6.1 mass $\%$ respectively. Coke has a relatively fine size and has high porosity which could explain its higher proportion in the emission. Furthermore, the $+0.3 \mathrm{~mm}$ fraction collected in the bags had a much higher coke content than the $-0.3 \mathrm{~mm}$ fraction (Table 7). This difference could be because particle entrainment depends on the ratio of particle surface area to weight- - large coke particles having relatively low specific gravity and high porosity are more easily entrained from the bed than an ore or flux particle of the same size.

$\mathrm{Cl}$ content of the $-0.3 \mathrm{~mm}$ fraction was higher than the $+0.3 \mathrm{~mm}$ fraction probably because of the presence of fine $\mathrm{KCl}$ fume.

\subsection{Influence of Burn-through Flow}

Burn-through flow was calculated as the average flow during the period when off-gas temperature begins to increase at the end of a run until maximum temperature is reached, as indicated earlier in Fig. 4. The burn-through flow was used to characterize the hydrodynamic conditions present at the end of the run when most of the particulate emission leaves the bed. To investigate the effect of burnthrough flow on emission the pressure drop across the bed was decreased just before burn-through occurred while maintaining other variables constant. As summarized in Table 8 for systems with and without Ore $\mathrm{M}$ a decrease in pressure drop caused a decrease in emission. This result

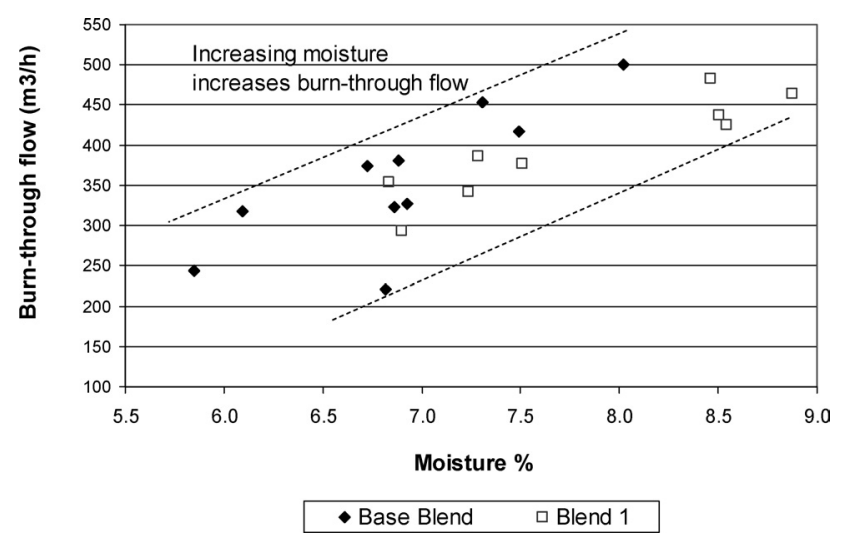

Fig. 6. Variation of burn-through flow with change in moisture.

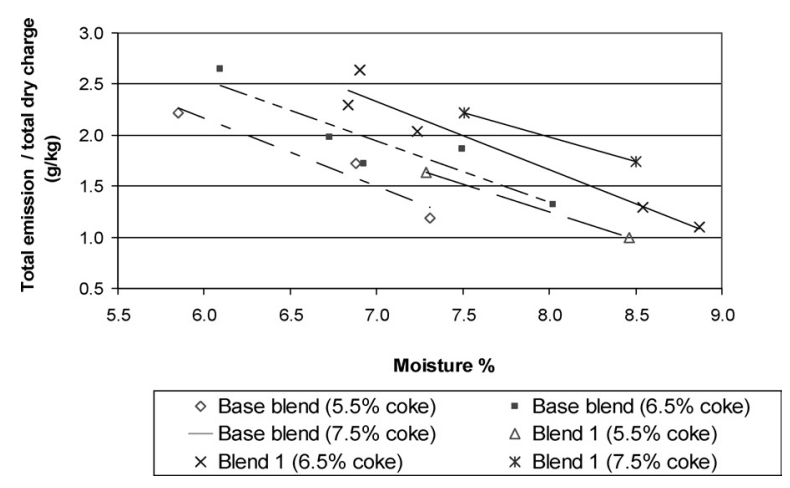

Fig. 7. Variation of total particulate emission/total dry charge versus change in moisture for different coke rates.

shows that decreasing the burn-through flow decreases the detachment forces which remove the particulate emission from a sintering bed.

It may be possible to reduce emissions on the plant by reducing the pressure drop across the bed for wind-boxes where burn-through occurs. However, a decline in productivity may occur because of a slower flame front speed.

\subsection{Influence of Green Mix Moisture}

In addition to bed pressure drop, the green mix moisture affected burn-through flow as shown in Fig. 6. Increasing moisture caused the burn-through flow to increase for both the Base blend and Blend 1. By increasing moisture granules can grow larger which increases bed voidage and this allows higher flows through. The results indicated that increasing moisture lead to a decrease in particulate emission for both the Base blend and Blend 1 at different coke rates, as shown in Fig. 7. The lines of best fit for the different cases were approximately parallel suggesting that the particulate emission level for each had a similar degree of sensitivity to variations in moisture. 


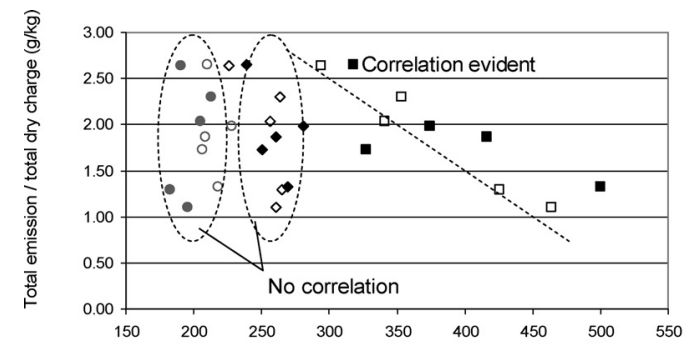

Burn-through flow, Post-ignition flow, Green bed flow ( $\mathrm{m} 3 / \mathrm{h}$ ) - Base blend (Green bed) $\quad \diamond$ Blend 1 (Green bed) Base blend (Sintering) Blend 1 (Sintering)

Fig. 8. Variation of total particulate emission/total dry charge plotted against burn-through flow, sintering flow and green bed flow for constant coke rate of 6.5 mass $\%$ dry ore basis while varying moisture.

A correlation between burn-through flow and particulate emission was observed when green mix moisture was varied, while weak correlations existed between green mix and sintering flow with particulate emission, as shown in Fig. 8. Unlike the effect of varying bed pressure drop, as burnthrough flow increased the total particulate emission decreased as green mix moisture was raised-in this case burn-through flow was not the only variable changing. This could be explained by considering granule structure. The formation of thicker layers of adhering fines on nuclear particles decreases the interfacial contact area between the flowing gas and particles. A higher moisture level could also help to form stronger bridges between particles through dispersing the clays present over a wider area. This result suggests that the increased burn-through flow and, hence, the increased detachment force was outweighed by the increased adhesion force as moisture was increased.

\subsection{Influence of Coke Rate}

Increasing the coke rate increased particulate emission for a given level of moisture, as shown in Fig. 7. Unlike moisture, there appeared to be no strong correlation between burn-through flow and coke rate. It has been shown that increasing coke rate while keeping moisture constant decreases sintering flow (determined at ambient condition) because of higher drag forces in the flame front zone. ${ }^{8)}$ Increasing coke rate will decrease gas density but its not clear what will happen to velocity since the expanded gas is accompanied by a reduced mass flow through the bed. The time available for the fine particles incorporated in the adhering fines layer to lift off is only short. By increasing the coke rate the drying zone will become broader which will increase the time available for particles to detach from the drying zone. This change may explain the increase in emission measured as coke rate was increased.

\subsection{Influence of Marra Mamba Ore}

Ore $\mathrm{M}$ was introduced into the blend to replace Ores $\mathrm{N}$, $\mathrm{C}$ and $\mathrm{B}$. Figure 2 shows that these ores have similar size distributions. The changes in fluxes additions because of differences in ore chemistry were only small (Table 1 ). As a consequence, introducing 30 mass $\%$ dry ore basis Ore $\mathrm{M}$ in the current work had a negligible impact on the size distribution of the sinter mix.

Sinter tests for the Base blend and Blend 1 that had a re-
Table 9. Particulate emission and sintering results for return fine balanced (RFB) tests.

\begin{tabular}{|l|c|c|c|c|c|c|c|}
\hline Description & \multicolumn{3}{|c|}{ Base blend } & \multicolumn{3}{|c|}{ Blend 1 } \\
\hline Test & $\mathrm{H}$ & $\mathrm{C}$ & $\mathrm{A}$ & $\mathrm{I}$ & $\mathrm{B}$ & $\mathrm{F}$ & $\mathrm{J}$ \\
$\begin{array}{l}\text { Moisture } \\
\text { (mass\%) }\end{array}$ & 6.1 & 6.9 & 7.5 & 8.0 & 6.8 & 6.9 & 7.2 \\
$\begin{array}{l}\text { Coke rate } \\
\text { (mass\% dry ore } \\
\text { basis [kg/t } \\
\text { sinter]) }\end{array}$ & $\begin{array}{c}6.5 \\
{[59.9]}\end{array}$ & $\begin{array}{c}6.5 \\
{[60.0]}\end{array}$ & $\begin{array}{c}6.5 \\
{[60.1]}\end{array}$ & $\begin{array}{c}6.5 \\
{[61.5]}\end{array}$ & $\begin{array}{c}6.5 \\
{[61.2]}\end{array}$ & $\begin{array}{c}6.5 \\
{[63.3]}\end{array}$ & $\begin{array}{c}6.5 \\
{[62.9]}\end{array}$ \\
$\begin{array}{l}\text { Total particulate } \\
\text { emission / total } \\
\text { dry charge (g/kg) }\end{array}$ & 2.65 & 1.72 & 1.86 & 1.32 & 2.30 & 2.64 & 2.04 \\
$\begin{array}{l}\text { RFB } \\
\text { TI (mass\% } \\
+6.3 \mathrm{~mm})\end{array}$ & 0.94 & 0.96 & 0.97 & 1.06 & 0.97 & 1.07 & 1.05 \\
$\begin{array}{l}\text { Productivity } \\
\text { (t/m2.d) }\end{array}$ & 67.5 & 68.6 & 66.2 & 66.1 & 66.3 & 65.3 & 64.2 \\
$\begin{array}{l}\text { Yield (mass\% } \\
+5 \mathrm{~mm})\end{array}$ & 66.3 & $\begin{array}{c}\text { Not } \\
\text { measur } \\
\text { ed }\end{array}$ & 42.4 & 39.5 & 41.7 & 38.9 & 41.4 \\
\hline
\end{tabular}

turn fines balance (RFB) close to 1.0 are summarized in Table 9. For balanced return fines, a wider range of mix moistures was used for the Base blend compared to Blend 1. This meant that the range in particulate emission obtained was wider. The particulate emission values for Blend $1(2.04-2.30 \mathrm{~g} / \mathrm{kg})$ were within the range measured for the Base blend $(1.32-2.65 \mathrm{~g} / \mathrm{kg})$.

The trend lines presented earlier showing the relationship between particulate emission and moisture (Fig. 7) or burnthrough flow (Fig. 8) for the Base blend and Blend 1 are quite similar. This could be because the particulate emission behaviour of these blends are quite similar. The current work shows that to evaluate the effect of an ore on particulate emission careful consideration of the moisture and coke rate in the blend is needed. Therefore knowing the optimum moisture and coke rate for a blend is needed to determine its effect on particulate emission.

\subsection{Mechanism of Particulate Release from a Sinter Bed}

For an experiment that was stopped as the flame-front approached the base of the bed, the mass of particulate emission collected was significantly less than other completed runs (i.e. $27 \mathrm{~g}$ collected for stopped run compared with an average of $166 \mathrm{~g}$ collected from completed runs). This result showed that most of the particulate emission comes out during the final stages of sintering. As the flame-front approaches the bottom of the bed the wet zone decreases in width and its ability to capture particulates diminishes. This result confirms that the removal of the wet zone at the final stages of sintering leads to the high levels of particulate emission from the bed at this time.

Bags used for particulate emission collection from the partially sintered bed were also inspected. Mostly fine $\mathrm{KCl}$ fume had been collected on the bags indicating that this fume was released from the bed during the entire run. The fume is very fine (i.e. sub-micron) and can pass through the wet zone because of its low inertia and ability to be entrained in the gas stream.

Analyses of the particulate emission from the Base blend (Test $\mathrm{A}$ ) and Blend 1 (Test $\mathrm{B}$ ) showed that the $\% \mathrm{CaO}$ of the total $\mathrm{CaO}$ present not associated with $\mathrm{CaCO}_{3}$ was $34.8 \mathrm{mass} \%$ and 42.3 mass $\%$ respectively, indicating that a significant amount of $\mathrm{CaO}$-containing material had come 
from the calcination zone. The low level of $\mathrm{Cl}$ in the particulate emission from Test A and Test B was 0.10 mass $\%$ and $0.12 \mathrm{mass} \%$ respectively, which indicates that the $\mathrm{KCl}$ component of the total particulate emission is quite small and that the dried and calcination zones was where most particulates came from.

The removal of excess water from the wet zone may play a part in washing some particles from the granulated bed. However, the small amount of particulate emission collected prior to the final stages of sintering $(\sim 17$ mass $\%)$ suggests this is only a minor contribution to the total particulate emission.

In the current work most of the particulate emission was $-1.18 \mathrm{~mm}$ (Fig. 5). The maximum particulate emitted probably depends on the voids between granules and in the hearth layer. The condensation of moisture in the wet zone could contribute to reducing the size of voids. Nuclear particles of granules are unlikely to be emitted even after calcination because they are protected by the adhering fines layer and tend to be locked up in the bed structure. Ultrafine particles (approximately $-38 \mu \mathrm{m}$ ) will adhere quite strongly to the bed because of their high ratio of surface adhesion to hydrodynamic forces-however these particles may also "piggy-back" on larger particles to leave the bed.

\section{Conclusions}

In the current work a particulate collection rig was connected to the off-gas pipe of the Newcastle Technology Centre laboratory sinter pot to capture the particulate emission under different conditions. A blend similar to that typically used in the Asia Pacific region and another containing 30 mass\% Marra Mamba ore were considered. The conclusions of the study are:

(1) Most particulate emission had size $-1.18 \mathrm{~mm}$ indicating that it comes mostly from the adhering fines layer of granules. The particulate emission becomes coarser as the flame front moves further down the bed.

(2) The particulate emission had coke levels estimated to be 5.5 mass $\%$ (Base blend) and 6.1 mass $\%$ (Blend 1) which were higher than the 4.0 mass $\%$ that was in the raw blend. The $\mathrm{Cl}$ content is higher in the $-0.3 \mathrm{~mm}$ fraction $(0.18-0.26$ mass $\%)$ than $+0.3 \mathrm{~mm}$ fraction $(0.036-0.11$ mass $\%$ ) of the particulate emission.

(3) Most particulate emission originates from the calcination and dried zones. The production of $\mathrm{KCl}$ fume and the entrainment of particles by water flowing from the bed also contribute but to a lesser extent. Most particulate emission comes from the bed at the end of sintering as the wet zone decreases in size until it cannot fully scrub the particles from the gas.

(4) Increasing moisture level (5.5-9.0 mass\%) decreased particulate emission level while increasing coke (5.5-7.5 mass \%) rate increased particulate emission level. These results indicate that variations in these critical control variables for the sinter operation have a significant impact on particulate emissions from the strand. Furthermore, to evaluate the effect of an individual ore on particulate emission, careful consideration of the optimum moisture and coke rate for the blend is required.

(5) Decreasing the pressure drop just before burnthrough caused a decrease in particulate emission.

\section{REFERENCES}

1) F. Cappel: Ironmaking Conf. Proc., Iron and Steel Society, Warrendale, PA, (1991), 525.

2) N. Margolis and R. Brindle: Energy and Environmental Profile of the U.S. Iron and Steel Industry-Report No. DOE/EE-0229, Energetics Incorportated, USA, (2000).

3) J. Khosa, J. Manuel and A. Trudu: Iron Ore Conf., Australasian Institute of Mining and Metallurgy, Carlton, Australia, (2002), 291.

4) C. E. Loo: Some Progress in Understanding the Science of Iron Ore Sintering, 1998 ICSTI/Ironmaking Conf., Ironmaking Division of the Iron and Steel Society, Warrendale, PA, (1998), 1299.

5) C. S. Teo, R. Mikka and C. E. Loo: ISIJ Int., 32 (1992), 1047.

6) J. G. Peacey and W. G. Davenport: The Iron Blast Furnace-Theory and Practice, Pergamon Press, Oxford, (1979), 154.

7) C. E. Loo, L. T. Matthews and J. Ostwald: Trans. Inst. Min. Metall. C, 101 (1992), C129.

8) C. E. Loo and M. F. Hutchens: ISIJ Int., 43 (2003), 630. 